\title{
Transtorno bipolar: sub ou superdiagnóstico no envelhecimento?
}

\author{
Luísa Weber Bisol
}

Médica Psiquiatra HSL-PUCRS, PhD em Ciências Biológicas: Bioquímica - UFRGS

Coordenadora do Ambulatório de Bipolaridade do HSL-PUCRS

$\mathrm{N}$ as últimas décadas evidenciou-se um aprimoramento significativo na habilidade dos psiquiatras de diagnosticar transtorno bipolar. É possível abordar essa questão como "uma faca de dois gumes".

Por um lado, muitos avanços ocorreram e o diagnóstico correto propiciou tratamento adequado para muitos indivíduos que passaram anos sofrendo os ônus de diagnósticos equivocados. Inúmeras situações de monoterapia com antidepressivos, uso de psicoestimulantes entre outras condutas ainda são vistas no dia a dia do psiquiatra. Uma avaliação mais apurada pode revelar quadros bipolares "ocultos" e oferecer melhores opções de tratamento.

A partir da disponibilidade dos antidepressivos inibidores seletivos da receptação de serotonina, muito mais seguros, bem tolerados e de fácil posologia, as prescrições de antidepressivos cresceram de forma exponencial. Parece muito mais tranquilo prescrever um antidepressivo quando compara-se com a prescrição de um estabilizador de humor. Só que isso pode trazer riscos aos bipolares. É possível induzir um episódio maníaco que muitas vezes é catastrófico na vida de um indivíduo.

Paralelamente a isso, há um certo "modismo". É muito comum ouvir pessoas leigas afirmarem "sou bipolar" ou mesmo profissionais da área de saúde mental darem esse diagnóstico em excesso. Dificuldade em observar melhor aspectos da personalidade e a pressão em dar logo um diagnóstico contribuem nesse sentido. Oscilações de humor podem ocorrer mesmo em pessoas sem qualquer transtorno mental e que essas mudanças devem ser contextualizadas. Como estaria outra pessoa que estivesse passando por uma situação semelhante? $O$ quanto esses sintomas estão trazendo prejuízo ou sofrimento significativos? Transtorno bipolar é um transtorno mental severo, com morbidade e mortalidade significativas. Deve-se ter cuidado para não banalizar o diagnóstico e fornecer justificativas para quaisquer comportamentos que fogem à etiqueta social.

É fundamental ter em mente esses dois lados na rotina da assistência em saúde mental. Encontrar a "coluna do meio" e não errar nem por falta, nem por excesso é o objetivo a ser perseguido. Não esquecer das antigas aulas de Semiologia Médica, observar o indivíduo, ouvir atentamente sua história clínica, realizar uma boa anamnese, pesquisar dados relevantes e fazer um exame do estado mental minucioso ainda são as nossas melhores ferramentas. Saber identificar quando é preciso ser rápido em tomar condutas para garantir a segurança do 
indivíduo e quando é possível ouvir mais e não ceder a pressão de um diagnóstico no final da primeira consulta é a parte "arte" da psiquiatria. Outro ponto que merece destaque é o manejo desses quadros na velhice. Nessa faixa etária, há dois grupos: aqueles que apresentaram o diagnóstico precocemente na vida e os que desenvolvem tardiamente. Ainda pairam muitas dúvidas com relação à distinção entre os dois subgrupos (início precoce e início tardio) e os princípios gerais que norteiam a conduta médica são semelhantes àqueles adotados nos mais jovens. Um cuidado maior é recomendado devido às alterações próprias do envelhecimento, presença de comorbidades e interações medicamentosas que trazem algumas peculiaridades no manejo do transtorno bipolar no idoso. Na Medicina contamos com duas formas de aprendizado indispensáveis e complementares: as aulas e os livros aliados a rotina de assistência ao paciente. 